\title{
Organic Reserves in Tropical Grasses under Grazing
}

\author{
Mariane Moreno Ferro', Anderson de Moura Zanine, Daniele de Jesus Ferreira², \\ Alexandre Lima de Souza1, Luiz Juliano Valério Geron ${ }^{3}$ \\ ${ }^{1}$ Department of Animal Science, Federal University of Mato Grosso, Cuiabá, Brazil \\ ${ }^{2}$ Department of Animal Science, Federal University of Maranhão, São Luís, Brazil \\ ${ }^{3}$ Department of Animal Science, State University of Mato Grosso, Cuiabá, Brazil \\ Email: dany dosanjos@yahoo.com.br, anderson.zanine@ibest.com.br
}

Received 5 August 2015; accepted 12 September 2015; published 15 September 2015

Copyright (C) 2015 by authors and Scientific Research Publishing Inc.

This work is licensed under the Creative Commons Attribution International License (CC BY).

http://creativecommons.org/licenses/by/4.0/

(c) (i) Open Access

\begin{abstract}
Inadequate management in recent times has been considered the main factor contributing to pasture degradation. A major reason for this is related to gross errors of grazing management as a consequence of the lack of knowledge of ecophysiological limits of forage. This review aimed to approach the importance of organic reserves for grasses under grazing. Therefore, the predominant effect of animal grazing is the reduction of leaf area which impacts on carbohydrate and nitrogen reserves and consequently the growth of tillers, leaves and roots. Grass growth after defoliation is related to organic reserves and rate of photosynthesis. The latter is affected by the level of canopy light interception of and by the reminiscent leaf area index. When grazing management is carried out with respect to the physiological limits of grass growth, the rate of dry matter accumulation will be quick and constant. In this aspect, grazing management consists of seeking an efficient balance between plant growth and consumption which will reflect on animal productivity. Therefore, a balance point among frequency and intensity of defoliation must be found to achieve greater animal production concerning the ecophysiological limits of the forage plants. So the challenge will be to find a balance between frequency and intensity of grazing to achieve greater production of animals respecting the eco-physiological limits of forage plants for each forage grass individually.
\end{abstract}

\section{Keywords}

Forage, Grazing Frequency, Grazing Intensity, Pasture Management

\section{Introduction}

Estimation by [1] indicates that agriculture production will not be able to feed world population until 2050, due

How to cite this paper: Ferro, M.M., de Moura Zanine, A., de Jesus Ferreira, D., de Souza, A.L. and Geron, L.J.V. (2015) Organic Reserves in Tropical Grasses under Grazing. American Journal of Plant Sciences, 6, 2329-2338. 
to the fact that as agricultural areas deteriorate, the world population is projected to reach 9 billion. By the year 2050, FAO predicts that the world food demand will require a production increase of $70 \%$. This increase means that 1 million tons of cereals and 200 million tons of agriculture products need to be added to the current production each year. [2] emphasized that agricultures in tropical environments, predominantly the ones that use little technology, need to improve their yields.

According to [2], food shortage will be exacerbated in tropical areas of developing countries due to low crop productivity, global warming and soil degradation resulting from the removal of tropical vegetation.

However, from 195 million hectares of pasture available in Brazil, 120 hectares are cultivated pastures, which grew by $12 \%$ between 1970 and 2010, while the nation's livestock grew by $215 \%$ and meat production by $440 \%$ [3]. However, more than $70 \%$ of cultivated pasture shows some stage of degradation and greater parts of it in advanced stages of degradation [3].

In this scenario, beef cattle production in Brazil is still characterized as extensive compared to meat exporting countries, with low production rates and a very low average stocking rate ( $0.8 \mathrm{UA} / \mathrm{ha})$, which results in a productivity rate lower than its potential [4] [5].

The improper management currently used in the pasture is considered the main factor responsible for pasture degradation. The major reason for this is related to gross errors in pasture management, and is a consequence of the lack of knowledge about the ecophysiological limits of forage plants.

[6], in a brief historic of the advances in research with tropical forage plants in pasture, emphasized the importance of including plant ecophysiology in research development with forage plants. According to [7] the main effect of animals on the pasture is defoliation, which reduces leaf area and consequently affects carbohydrate reserves, tillering and growth of new leaves and roots.

Growth of forage plants after defoliation is related to the level of light interception by the canopy and its residual leaf area. The dry matter accumulation will be constant when there is enough foliage to substantially intercept all incident lights [8].

In general, the regrowth curve after grazing is characterized by three distinct stages. In the first phase, means of dry matter accumulation rate increase exponentially with time. This phase is influenced by organic reserves of the plant, availability of growth factors and reminiscent leaf area. The second phase presents constant means of accumulation rate (linear phase), and it occurs when inter- and intra-competition processes become more relevant, mainly when the canopy intercepts almost all incident lights. The third phase shows the reduction of accumulation rate means causing a reduction in the growth rate. This fact is a consequence of the increasing leaf senescence after their life time limit has been reached, and the increase of shading on inferior (older) leaves [6].

The essence of pasture management consists of maintaining an efficient balance between plant growth, its consumption and animal production to retain the productivity of the plant-animal system. Therefore, a balance point should be sought in the combination of frequency and intensity of defoliation for the species and/or cultivar concerning the ecophysiological limits of forage plants, in order to reach high levels of animal production.

Establishing this optimal point on pasture harvest for grazing animals is complex, however. [9] emphasizes that the difficulty in achieving this aim is the variation of this balance point according to the species of the forage and other factors from handling and the environment such as soil fertility, temperature, luminosity and water availability.

Considering the environmental effects added by soil fertility as major factors for plant growth by fixing carbon via photosynthesis. [10] and [11] highlighted that primary productivity of a pasture is basically determined by the amount of carbon accumulated per unit of soil area and unit of time. Carbon is the main constituent of vegetable tissue and its accumulation rate is determined by the rate of its photosynthetic assimilation by the plants. Carbon accumulation is influenced by nitrogen content in vegetable tissue, which means that the dynamics of these two nutrients' roles in plant development are intimately associated.

The knowledge of this dynamic is necessary because of the balance of carbon, nitrogen and water flow presents distinct responses according to defoliation regimes. Carbon supply after severe defoliation is mainly dependent on the dynamic of leaf area expansion. In continuously grazed pasture, this supply is determined by its leaf area index (LAI). According to [12], LAI is the ratio between the leaves' area and the soil surface that it is covered by them ( $\mathrm{m}^{2}$ of leaves/ $\mathrm{m}^{2}$ of soil).

This review aimed to approach the importance of organic reserves for grasses under grazing. 


\section{Photosynthesis}

Photosynthetic activity of the plants promotes the conversion and the storage of solar energy into energy-rich organic molecules from simple inorganic molecules, such as $\mathrm{CO}_{2}$ and $\mathrm{H}_{2} \mathrm{O}$ [13].

The light is a component of the broad spectrum of electromagnetic radiation from the Sun, and which is propagated as waves. Light with slightly superior frequency (lower wave length) is on ultraviolet range, and light with slightly inferior frequency (longer wave length) is on ultra-red range [14] (Figure 1).

Mesophyll is the most active tissue of photosynthetic tissues because of the large amount of chloroplasts which contain the pigment chlorophyll (a specialized pigment for light absorption). Chlorophyll A absorbs light radiation in a range of 420 to $660 \mathrm{~nm}$; chlorophyll B absorbs in a range of 435 to $625 \mathrm{~nm}$, chlorophyll C in a range of 445 to $625 \mathrm{~nm}$, and chlorophyll $\mathrm{D}$ in a range of 450 to $690 \mathrm{~nm}$. Carotenoids are the second most abundant group of pigments. They absorb the light at a wave length between 400 and $500 \mathrm{~nm}$, and transfer it rapidly to the chlorophylls, being characterized as accessory pigments. These pigments also have another role in the plant asphotoprotectors, an important mechanism of photochemistry apparatus [14].

Chloroplasts have in their extensive system of internal membranes the thylakoids, where all the chlorophyllis inserted. In the thylakoids there are reactions of light absorption by the pigments, the reduction of an electron acceptor called NADP (nicotinamide adenine dinucleotide phosphate) to $\mathrm{NADPH}_{2}$ (its reduced form), and the formation of ATP (adenosine triphosphate), which are reactions from the light phase.

A reduction of $\mathrm{CO}_{2}$ to triose phosphate, via the Calvin cycle also occurs in the thylakoids. These reactions are coupled with the consumption of NADPH and ATP synthesized in the light phase. The carbohydrates synthesized in the Calvin cycle are predominantly converted to sucrose and starch, which are forms of energy and carbon storage [1].

\section{Carbon Flow in the Plants}

Part of the carbon assimilated by the plants is used to produce energy to maintain existing tissues called maintenance respiration, with the other part used for the synthesis of new tissues called growth respiration. The energy produced by maintenance respiration is predominantly used in protein metabolism, maintenance of chemical gradient, membrane integrity and active ion transport. The assimilation of carbon represents the amount of this element which can be used to produce new tissues, and it may reach $50 \%-60 \%$ of the total photosynthesis of the canopy [15].

The solutes are preferentially trans located from production areas, known as sources, to metabolism or storage areas, known as sinks [15]. According to [14], the transport of the solute occurs through phloem which is

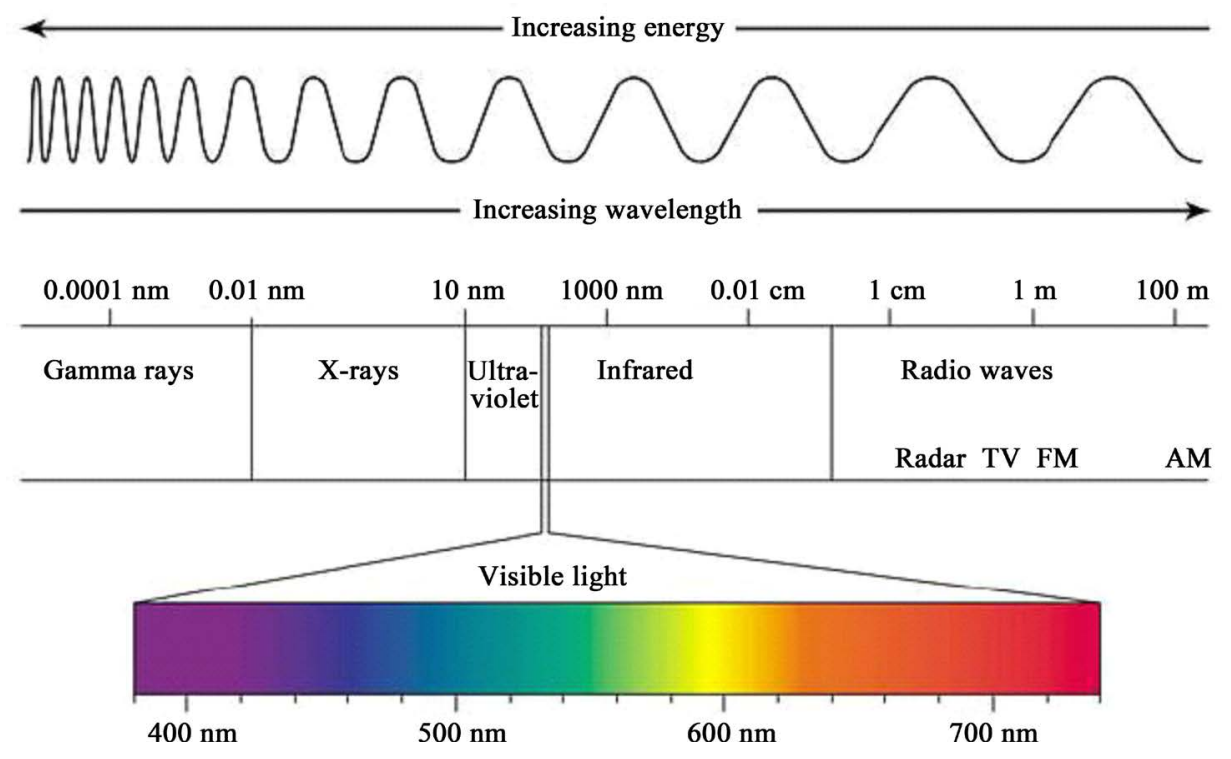

Figure 1. Spectrum of electromagnetic radiation in a range of 380 to $750 \mathrm{~nm}$ which is visible to human eyes and absorbed by plants to be used in photosynthesis [14]. 
constituted of sieve elements, parenchyma and companion cells. Characteristic of these sieve elements is the presence of sieve plates which allow the connections among several cells to create a sieve tube, where photoassimilates circulate.

The transport of sugars through phloem may occur between distant organs, but normally a sink of photoassimilates is supplied by closer sources. The source to sink ratio of the plant changes continually as the plant develops. As the development of new leaves occurs, photosynthetic activity of older leaves decreases and the process of senescence begins, in which there is mainly translocation of nitrogen from older leaves to youngest ones [16] [17]. Apical leaves supply vegetative apical buds, central leaves, the apex and the roots; and the basal ones mainly supply the roots.

However, plant defoliation can alter the partition pattern of assimilates. According to [18] and [19] assimilates exporting from lower leaves of barley (Hordeum vulgare L.), that in intact plants were predominantly for the radicular system, was reverted in favor of the terminal meristem immediately after defoliation, a process in which there was a removal of younger leaves.

The sources include any exporter organ and typically expanded leaves that are capable of producing photosynthate in excess of its own needs. The sinks include non-photosynthetic organs and organs that do not produce enough photo assimilates to meet their own requirements of growth or storage. The grass contains roots, leaves with long expansion and senescence times, stems and seeds [15]-[24].

During the vegetative stage, apical and radicular meristems are more important, but during reproduction stage fruits become preferential sinks, because the sources send photo-assimilate to the sinks that they have direct vascular connections [20].

Individual leaves present a large variation in their photosynthetic capacity, which is determined by many factors such as the amount of incident solar radiation, temperature, water and nutrient supplies and, predominantly, the development stage. The environments in which leaves develop also affect photosynthetic efficiency. Leaves growing in low radiation rate or in dense pasture have lower photosynthetic efficiency when emerging to the top of the canopy than leaves growing in high radiation rates after defoliation [21] as can be seen in the rotational stocking method example.

Leaves completely expanded perform photosynthesis with maximal intensity and assimilates performed by them will be used not only for their own maintenance, but also to meet the requirements of the apical meristem, radicular system and expanding leaves. A leaf with a partially exposed blade does not offer assimilates to other parts of the tiller, using it all for its own development and is characterized as a sink leaf. Expanding leaves present $38 \%$ of photosynthetic efficiency, completely expanded young leaves present $40 \%$, old leaves about $18 \%$ and exposed sheath $4 \%$ [22].

The partition process of solute determines its growth pattern and this growth should be balanced between the aerial part (photosynthetic productivity) and the roots (mineral and nutrient absorption). Therefore, there is an additional control in the interaction between supply and demand areas [15].

[23] evaluated the distribution of photo-assimilates in Panicum maximum cv Mombaça and observed that the partition of ${ }^{14} \mathrm{C}$ in the whole plant reached means of $82.5 \%$ in the aerial component and $17.5 \%$ for radicular component. While the portion referent to the aerial component was distributed in equal parts for the tiller which had exposed leaves (40\%) and for the other tillers (42.5\%), a greater fraction was exported for the radicular component between the other tillers (13.2\%) compared with the tiller with exposed leaves (4.3\%).

Leaf area which is photosynthetically active is extremely important. Leaves that are not properly lit, due to the shade from superior leaves, are considered more as a sink than as a source. In dicotyledon leaves, only $30 \%$ to $60 \%$ of their maximal leaf area are reached before they become autotrophic and then photo-assimilate exporters. In grasses such as sugar cane, the importation of carbohydrate by the phloem is maintained until the leaf reaches $90 \%$ of its maximal leaf area [2].

According to [21], non-structural carbohydrates comprehend the carbohydrate fraction that is stored in storage structures and operate in various biochemical processes. Normally, non-structural carbohydrate accumulated in tissue reserves are monosaccharaides, specifically hexoses (glucose and fructose), oligosaccharides (sucrose, maltose, and in lower amounts raffinose, stachyose, mannose, arabinose and xylose) and polysaccharides (starch and fructosans).

\section{Nitrogen Flow in the Plant}

Nitrogen $(\mathrm{N})$ is mainly absorbed in its inorganic form as nitrate $\left(\mathrm{NO}^{3-}\right)$ which is converted to nitrite $\left(\mathrm{NO}^{2-}\right)$ and 
finally to ammonia $\left(\mathrm{NH}_{3}\right)$ with some of its $\mathrm{N}$ directly absorbed as ammonium $\left(\mathrm{NH}_{4}^{+}\right)$. After absorption the molecules are metabolized to $\mathrm{N}$-amide of glutamine and transported in the phloem, predominantly in the form of amino acids and amide.

In this way, as described by [25], the $\mathrm{N}$ is considered an essential component for the synthesis of amino acids and proteins, nucleic acids, hormones, chlorophyll and other organic composts that are essential for the plant life. The nitrogen demand varies with the plant species and the nitrogen content varies with the part of the plant that is analyzed.

The nitrogen flow and its effect on the dynamic of plant growth and the carbon flow in the ecosystem are determined by the absorption rate of $\mathrm{N}$ and its distribution among the organs of the plant. When nitrogen availability in the soil is not limiting for the plant, the minimum percentage of nitrogen required to reach the maximum growth rate appears to decrease regularly as the plant grows [26]. This results in a decrease of $\mathrm{N}$ content per unit of leaf area as the leaves are progressively shaded, due to LAI development [27] [28].

According to [29], as the plant develops, a larger proportion of leaves are shaded and part of the nitrogen of these leaves is reallocated for growing leaves. This apparent reduction in $\mathrm{N}$ requirements for an extra leaf area expansion is accompanied by a supplementary nitrogen investment in the supporting stems or supporting tissues for the growth of new leaves in the top of the canopy, in lit areas. As the canopy develops, the competition for light increases, and then the compensation of $\mathrm{N}$ investment commences in photosynthetic tissues with high concentrations of this nutrient.

However, for proper growth the concentration should remain in a range of 20 to $50 \mathrm{~g} / \mathrm{kg}$ dry matter. When $\mathrm{N}$ supply is inadequate, the growth is retarded and $\mathrm{N}$ from older leaves is mobilized to areas with new growth [30].

Some studies show that a decrease in nitrate $\left(\mathrm{NO}_{3}^{-}\right)$supply to the radicular system can decrease the photosynthetic rate, promoting a decrease in carbohydrate supply to the roots [11]-[14]. A decrease of $50 \%$ in $\mathrm{NO}_{3}^{-}$ flow can reduce leaf area by up to $30 \%$ [11].

\section{Organic Reserves in the Grass}

A diversity of studies indicate that, as the stress imposed by the environment increases, the effects caused on plant growth will be greater, implying greater care for the frequency and intensity of defoliation. The morphologic and physiologic characteristics of the plant should be considered to avoid pasture degradation for the duration, and to obtain an adequate forage production and animal gain.

Physical condition of the soil, nutrients, humidity, temperature and the level of defoliation have a great influence on the forage production and, consequently, on animal production. These factors act directly on the radicular system, which is the support and the basis for tiller and leaf production and, therefore, forage production [31].

[32] highlighted two publications that contributed to improve the understanding of ecophysiological management of the pasture.

The first one was Graber's study in 1927, mentioned by [33] which was one of the first authors to report that the level of non-structural carbohydrate in the roots decreased during the spring regrowthof alfalfa (Medicago sativa) and after defoliation.

The second publication was Witson's study, cited by [34], which introduced the concept that leaf area measurement would be important to compare agriculture productivity, which means, the weight of different harvest produced per unit of soil area. This measurement would be related to leaf area per unit of soil surface, called Leaf Area Index (LAI), as previously mentioned in this paper.

Following this, Gomide (1973) cited by [6], in the first symposium about forage plant handling, emphasized the importance of the LAI concept, tillering, storage of carbohydrate, and the intensity and frequency of defoliation for pasture handling.

Studies of [35] showed that organic reserves were not the primary source of carbon after 3 days and nitrogen compounds at 4.5 days of regrowth for Lolium perenne L., moments in which more than $50 \%$ of carbon and nitrogen content of growth zones were recently assimilated. These results indicate that the period where organic reserves are the primary source of nitrogen and carbon for growth, following the defoliation process in the grass, is shorter than what was accepted in the literature previously (one week for carbon and one to two weeks for nitrogen).

In another study, [36] observed shorter contribution of organic reserves for regrowth of Lolium perenne L. In 
this study, on the second day after defoliation, photosynthesis represented the primary source of carbon for leaf growth. Thus, carbon from aminoacids was approximately $60 \%$ of carbon inflow derived from organic reserves during this period of two days.

Nitrogen reserves were not the primary source of $\mathrm{N}$ for tiller growth after defoliation, and reserve carbohydrate was insignificant as a carbon source for tiller growth after the first day of regrowth. However, according to the same authors, the contribution of reserve carbohydrate for tiller regrowth is considered indirect, via aerial component supply and maintenance of integrity and functionality of the roots.

According to [37], the removal of the aerial component by cutting or grazing represents a stress for the plants, whose magnitude depends on the intensity of the defoliation. Defoliation reduces light interception, canopy photosynthesis, the amount of organic compound reserves and root growth.

Evaluating four different intensities of defoliation (main tiller kept intact, superior defoliation, inferior defoliation and total defoliation) in Mombaçagrass [38] observed a pronounced decrease in non-structural carbohydrate content for all intensities on the second day of regrowth. The content started to recover from the fifth day, but starting content was not reestablished after 16 days, and a more intense effect was also observed for total defoliation compared to superior defoliation and the control.

An evaluation made by [39] pointed out that forage plant physiology after defoliation presents two distinct phases. The first one consists of a transitory period, where organic reserves stored are used as a rapid reposition of removed tissues in defoliation. The second phase involves a readjustment of physiologic activity where the reserves are progressively reestablished.

According to [40], if the height of grazing or cutting favors the maintenance of adequate LAI, an adequate light interception will occur, favoring initial growth of the plants. Therefore, management is important to improve recuperation and forage production. Thus, carbohydrate reserves used by the plant should also be considered as nutrients for its own maintenance and future development of tillers and roots.

From this [41] evaluated different cultivars of Cynodon spp. (Tifton-85, Florakirk and Coastcross) with different heights $(5,10,15$ and $20 \mathrm{~cm})$, maintained by grazing sheep in a continuous stocking method with variable stocking rate and verified that non-structural carbohydrate content did not change in relation to the heights for the stem or root bases studied. This is possibly related to the fact that the lower pasture height studied $(5 \mathrm{~cm})$ was not drastic enough to promote a reduction in the carbohydrate content in relation to others.

An experiment was developed by [42] with pasture of Marandu grass in a continuous stocking method, kept at heights of 10, 20, 30 and $40 \mathrm{~cm}$, and LAI of 1.7, 3.5, 4.0 and 3.8 respectively. The author observed that the optimal range was between 20 to $40 \mathrm{~cm}$ for forage production, and that pasture kept at $10 \mathrm{~cm}$ showed a decrease in organic reserves (carbon and nitrogen) throughout the experiment, which indicates that this is an unstable condition for Marandu grass.

Evaluating supply levels of elephant grass cv. Mott dry matter, under continuous grazing, [43] observed carbohydrate contents of $8.1 \%$ to $10.9 \%$ for 250 and $2500 \mathrm{~kg}$ DM of remaining leaves. The authors also registered that, in pasture grazed under rotational stocking, greater intensities of grazing (250 and $900 \mathrm{~kg}$ of DM of residual leaves) and greater grazing frequencies were responsible for lower concentrations of non-structural carbohydrates.

According to [44], the recuperation of leaves from defoliation depends on remaining leaf area, because an inverse relation between initial leaf area speed and the level of defoliation of the plants was observed.

Evaluating four forage offers (1978, 2130, 2545 and $3857 \mathrm{~kg}$ DM/ha of Croast-cross grass (Cynodon dactylon (L.), in a continuous stocking method with variable stocking rates, [45] observed that as DM increased, carbohydrate content in stem base reduced until reaching an approximate level of $2545 \mathrm{~kg} \mathrm{DM} / \mathrm{ha}$, and from this, the increase was more pronounced reaching the highest content of $3.86 \%$ of the treatment with $3857 \mathrm{~kg} \mathrm{DM} / \mathrm{ha}$.

It is noteworthy that the roots are important for forage growth, because it supports the aerial component [45]. [46] observed that the biomass partition of the radicular system is $75.13 \%$ when the plant's depth is in a range of $0-10 \mathrm{~cm}, 15.21 \%$ for $10-20 \mathrm{~cm}$ and $9.66 \%$ for $20-40 \mathrm{~cm}$.

In this context, [47] studied the behavior or radicular mass of pangola grass and verified a reduction by $50 \%$ under high grazing pressure (10.5\% of live weight) in relation to low grazing pressure (3.5\% of live weight). This effect explains the fact that depending on defoliation level, radicular growth is reduced, stops or causes root death as a consequence of the lack of energy from photosynthesis.

After defoliation, there is a decrease in the transport of assimilates for the roots due to rapid recovery of foliar area [38]. It is important to note that after grazing, the roots have a lower priority in relation to foliar growth due 
to the re-establishment of the plant's photosynthetic capacity, and the prevention of reserve exhaustion.

[41] evaluated the amount and content of non-structural carbohydrate and the accumulation rate of dry matter for Cynodon spp. pasture during winter, spring and summer seasons, verifying that the carbohydrate content of non-structural carbohydrate in the roots increased from mid-spring (7.05\%), overcoming those observed for the stem base from this period.

This pattern of behavior suggests that cultivars have seasonal variation for the allocation of photo-assimilates in their different reserve organs. This probably indicates the existence of a mechanism used by the plants to ensure their survival during the winter, and as a preparation for the flowering, which is a phonological event that demands high energy supply. Also, the reduction in the value of stem base (5\%) concomitantly to the increase of the base of the roots is probably related to the use of these reserves on plant growth, as a higher accumulation rate was verified during the same period.

A variety of studies have focused on the idea that not only non-structural carbohydrate, but also nitrogen reserves, are fundamental factors for prompt regrowth of the plant after cutting or grazing [42].

Evaluating two doses of nitrogen fertilizer (150 and $300 \mathrm{~kg} / \mathrm{ha}$ ) on radicular growth of the grasses Tanzânia and Aruana, [48] observed that Tanzania grass presented a higher radicular mass at a dose of 300, and Aruana grass did not presented any changes according to the doses used. Grazing cycles in the autumn presented lower radicular mass compared to winter, spring and summer, that did not presented differences among themselves. Grazing cycles are influenced by factors such as precipitation, temperature and LAI which impact on the growth of aerial components.

[49] evaluated doses of nitrogen fertilization $(0,50,100$ and $150 \mathrm{~kg}$ of $\mathrm{N} / \mathrm{ha})$ in Tanzania grass pasture and observed that the 50 and $100 \mathrm{~kg} / \mathrm{ha}$ doses were similar and showed a higher accumulation of non-structural carbohydrate for roots during autumn and spring. Areas where $150 \mathrm{~kg} / \mathrm{ha}$ was applied presented a lower non-structural carbohydrate content. This fact can be explained by the accelerated growth which certainly impacted the greater growth of the leaves and stems due to higher $\mathrm{N}$ availability (from the fertilizer) which allowed the forage plant to mobilize larger amounts of non-structural carbohydrate for regrowth.

[50], working with alfalfa, observed that two weeks after cutting, $40 \mathrm{~kg}$ of N/ha was apparently mobilized by the roots for the aerial component.

Similar to the observations of [50], who described that about $80 \%$ of the nitrogen present in the aerial component formed in the first week after grazing or cutting may come from the translocation of roots and stems, with the other part coming via soil absorption. However, [51], affirmed that the remobilization pattern of these nitrogen reserves towards the new tissue is associated to the amount of nitrogen present in the soil-plant system.

A study carried out by [52],) with Xaraés grass submitted to different doses of nitrogen and potassium evaluated the amount and content of these compounds, as well as dry matter production in the roots, crown and base of stem. It was observed that nitrogen doses influenced the total $\mathrm{N}$ content of the roots and base of stem. This result shows that in situations where the amount of nitrogen in the soil is lower than these requirements, cultivarsdo not accumulate nitrogen in tissues of the roots or base of stem.

These results reinforce the need for studies that relate to nitrogen reserves in the plants as a factor for the influence of forage recovery after defoliation, and the best period for nitrogen fertilization.

According to [52] and [53], the supply of nitrogen affects growth and morphology of the roots, with root density increasing quickly in areas with higher nutrient concentrations.

\section{Conclusions}

The knowledge of ecophysiological characteristics of forage plants is fundamental to implant management strategies.

Previously, it was believed that initial regrowth of the pasture after defoliation depended on organic reserves; some studies have shown that reserves were used up to two weeks in pasture regrowth. This was related to the type of management used, because these were not studies using LAI, which is a factor that is closely related to efficient pasture regrowth after defoliation without disrupting biomass production.

The addition of the concept of LAI should consider intensity and frequency of grazing on grazing management strategies. This will enable the reminiscent leaf area to be photosynthetically efficient to generate photoassimilates for new leaves and tillers and to recover organic reserves.

Nutrient availability in the soil is fundamental for pasture development and its recovery after defoliation.

The challenge will be to find a balance between frequency and intensity of grazing to achieve greater 
production of animals while respecting the ecophysiological limits of forage plants for each forage grass individually.

Future research may include in their study protocols, evaluation of soluble carbohydrate and nitrogen reserves correlating with the frequencies and grazing intensities.

\section{Acknowledgements}

Coordination of Improvement of Higher Education (CAPES).

\section{References}

[1] Food and Agriculture Organization of the United Nations (FAO) (2013) How to Feed the World in 2050. http://www.fao.org/fileadmin/templates/wsfs/docs/expert_paper/How_to_Feed_the_World_in_2050.pdf

[2] Pimentel, C. (1998) Metabolismo de carbono na agricultura tropical. 1 ed., Seropédica: Edur, 2, 150 p.

[3] Zimmer, A.H. and Macedo, M.C.M. (2010) Recuperação de pastagens degradadas. Seminário de Sensibilização do Programa ABC-Agricultura de Baixa Emissão de Carbono. Embrapa Gado de Corte, 4, 200 p.

[4] Pereira, O.G., Gobbi, K.F. and Pereira, D.H. (2006) Conservação de Forrageiras como opção para o manejo de pastagens. Revista Brasileira de Zootecnia, 43, 138-159.

[5] Ferreira, D.J. and Zanine, A.M. (2014) Challenges Facing Pasture in The Context of Agricultural Multifunctionality in Brazil. American Journalof Experimental Agriculture, 4, 1793-1811. http://dx.doi.org/10.9734/AJEA/2014/12597

[6] Da Silva, S.C. and Nascimento Jr., D. (2007) Avanços na pesquisa com plantas forrageiras tropicais em pastagens: características morfofisiológicas e manejo do pastejo. Revista Brasileira de Zootecnia, 36, 121-138. http://dx.doi.org/10.1590/S1516-35982007001000014

[7] Zanine, A.M., Nascimento Jr., D., Sousa, B.M.L., Silveira, M.C.T. and Silva, W.L. (2013) Tillering Dynamics in Guinea Grass Pastures Subjected to Management Strategies under Rotational Grazing. Revista Brasileira de Zootecnia, 42, 155-161. http://dx.doi.org/10.1590/S1516-35982013000300002

[8] Zanine, A.M., Nascimento Jr., D., Pena, K.S., Da Silva, S.C. and Sbrissia, A.F. (2011) Características estruturais e acúmulo de forragem em capim-tanzania sob pastejo rotativo. Revista Brasileira de Zootecnia, 40, 2364-2373. http://dx.doi.org/10.1590/S1516-35982011001100012

[9] Nascimento Jr., D.D. and Adese, B. (2004) Acúmulo de biomassa na Pastagem. Anais... II Simpósio sobre manejo estratégico da pastagem. Universidade Federal de Viçosa. Viçosa-MG, 2, 85-104.

[10] Montagner, D.B. (2004) Fluxos de carbono e Nitrogênio em pastos sob pastejo. In: Simpósio sobre Manejo de Pastagens, Viçosa-MG, 2, 55-175.

[11] Zanine, A.M. and Ferreira, D.J. (2015) Animal Manure as a Nitrogen Source to Grass. American Journal of Plant Sciences, 6, 899-910.

[12] Costa, N.L., Magalhães, J.A., Townsend, C.R. and Paulino, V.T. (2004) Fisiologia e Manejo das Plantas Forrageiras. Embrapa Rondônia, 3, 27 p.

[13] Majerowicz, N. (2004) Fotossíntese. In: Kerbauy, G.B., Ed., Fisiologia Vegetal, 2nd Edition, Guanabara, São Paulo, 114-178.

[14] Rosa, L.M.G. (2004) Fotossíntese: As reações luminosas. In: Zeiger, T., Ed., Fisiologia Vegetal, 3rd Edition, Artmed, Porto Alegre, 139-172.

[15] Santarém, E.R. (2004) Translocação no Floema. In: Zeiger, T., Ed., Fisiologia Vegetal, 3rd Edition, Artmed, Porto Alegre, 221-250.

[16] Wardlaw, I.F. (1990) Tansley Review No. 27: The Control of Carbon Partitioning in Plants. New Phytologist, 116, 341-381. http://dx.doi.org/10.1111/j.1469-8137.1990.tb00524.x

[17] Zanine, A.M. and Santos, E.M. (2008) Senescência e acúmulo líquido de forragem. Revista Científica Rural, 12, 113125.

[18] Ryle, G.J. and Powell, C.E. (1975) Defoliation and Regrowth in the Graminaceous Plant: The Role of Current Assimilate. Annals of Botany, 39, 297-310.

[19] Ryle, G.J.A., Powell, C.E. and Gordon, A.J. (1985) Short-Term Changes in $\mathrm{CO}_{2}$ Evolution Associated with Nitrogenase Activity in White Clover in Response to Defoliation and Photosynthesis. Journal Experimental Botany, 36, 634643. http://dx.doi.org/10.1093/jxb/36.4.634

[20] Rodrigues, L.R.A. (1984) Morphological and Physiological Responses of Dwarf Elephant Grass (Pennisetum purpureum (L.) Schum.) to Grazing Management. Thesis (Doctor of Philosophy), University of Florida, Gainesville 192 p. 
[21] Lemaire, G. (1997) The Physiology of Grass Growth Under: Tissue Turnover. In: Simpósio Internacional sobre Produção Animal em Pastejo, Universidade Federal de Viçosa, Anais... Viçosa, 117-144.

[22] Pedreir, A.C.G.S., Mello, A.C.L. and Otani, L.O. (2001) Processo de produção de forragem em pastagens. In: Reunião Anual da Sociedade Brasileira de Zootecnia, FEALQ, Anais...Piracicaba, 772-807.

[23] Alexandrino, E., Gomide, J.A. and Gomide, C.A.M. (2005) Crescimento do dossel de Panicum maximum “cv” Mombaça. Revista Brasileira de Zootecnia, 34, 2164-2173. http://dx.doi.org/10.1590/S1516-35982005000700002

[24] Moore, K.J. and Hatfield, R.D. (1994) Carbohydrates and Forage Quality. In: Fahey, G.C., Ed., Forage Quality, Evaluation, and Utilization, American Society Agronomy, Madison, 229-280.

[25] Rodrigues, R.C., Mourão, G.B. and Valinote, A.C. (2007) Reservas Orgânicas, Relação Parte Aérea Raiz e C-N e Eliminação do Meristema Apical no Capim-Xaraés Sob doses de Nitrogênio e Potássio. Ciência Animal Brasileira, 8, 505-514.

[26] Gastal, F. and Durand, J.L. (2000) Effects of Nitrogen and Water Supply on N and C Fluxes and Partitioning in Defoliated Sward. In: Lemaire, G., Hodgson, J., de Moraes, A., Nabinger, C. and de F. Carvalho, P.C., Eds., Grassland Ecophysiology and Grazing Ecology, CAB International, Wallingford, Oxfordshire, 105-143. http://dx.doi.org/10.1079/9780851994529.0015

[27] Lemaire, G., Onillion, B. and Gosse, G. (1991) Nitrogen Distribution within a Lucerne Canopy during Regrowth: Relation with Light Distribution. Annals of Botany, 68, 483-488.

[28] Dourado, R.L., Souza, A.L., Zanine, A.M., Toral, F.L.B., Ferreira, D.J. and Abreu, J.G. (2015) Structural and Production Characteristics of Piatã Grass Forage Submitted to Levels of Nitrogen. American Journal of Plant Sciences, 6, 693-701. http://dx.doi.org/10.4236/ajps.2015.65075

[29] Grindlay, D.J.C., Sylvester-Bradley, R. and Scott, R.K. (1993) Nitrogen Uptake of Young Vegetative Plants in Relation to Green Area. Journal Sciences Food Agriculture, 63, 116-128.

[30] Furlani, A.M.C. (2004) Nutrição Mineral. In: Kerbauy, G.B., Ed., Fisiologia Vegetal, Guanabara, São Paulo, 40-75.

[31] Cecato, U., Cano, C.C.P. and Bortolo, M. (2001) Teores de Carboidratos Não-Estruturais, Nitrogênio Total e Peso de Raízes em Coastcross-1 (Cynodon dactylon( L.) Pers) Pastejadopor Ovinos. Revista Brasileira de Zootecnia, 30, 644650. http://dx.doi.org/10.1590/S1516-35982001000300006

[32] Da Silva, S.C. and Nascimento Jr., D. (2006) Sistema Intensivo de Produção de Pastagens. II Congresso LatinoAmericano de Nutrição Animal (II CLANA). Manejo e Nutrição de Ruminantes, São Paulo, 25-41.

[33] Volenec, J.J., Ourry, A. and Joern, B.C. (1996) A Role for Nitrogen Reserves in Forage Regrowth and Stress Tolerance. Physiologia Plantarum, 87, 185-193. http://dx.doi.org/10.1111/j.1399-3054.1996.tb00496.x

[34] Black, J.N. (1962) The Interrelationship of Solar Radiation and Leaf área Index in Determining the Rate of Dry Matter Production of Swards of Subterranean Clover (Trifolium subterraneum L.). Australian Journal Agricultural Research, 14, 20-37. http://dx.doi.org/10.1071/AR9630020

[35] De Visser, H. (1997) Nutrient Fluxes in Splanchnic Tissue of Dairy Cows: Influence of Grass Quality. Journal of Dairy Science, 80, 1666-1673. http://dx.doi.org/10.3168/jds.S0022-0302(97)76098-3

[36] Schnyder, H. and De Visser, R. (1999) Fluxes of Reserve-Derived and Currently Assimilated Carbon and Nitrogen in Perennial Ryegrass Recovering from Defoliation. Plant Physiology, 119, 1423-1435. http://dx.doi.org/10.1104/pp.119.4.1423

[37] Davidson, J.L. and Milthorpe, F.L. (1966) Leaf Growth of Dactylis glomerata L. Following Defoliation. Annals of Botany, 30, 173-184.

[38] Gomide, C.A.M., Gomide, J.A. and Huaman, C.A.M. (2002) Fotossíntese, Reservas Orgânicas e Rebrota do CapimMombaça (Panicum maximum Jacq.) sob Diferentes Intensidades de Desfolha do Perfilho Principal. Revista Brasileira de Zootecnia, 31, 2165-2175. http://dx.doi.org/10.1590/S1516-35982002000900003

[39] Morvan-Bertrand, A., Pavis, N., Boucaud, J. and Prud'homme, M.P. (1999) Partitioning of Reserve and Newly Assimilated Carbon in Roots and Leaf Tissues of Lolium perenne during Regrowth after Defoliation: Assessment by C-13 Steady-State Labeling and Carbohydrate Analysis. Plant Cell and Environment, 22, 1097-1108.

[40] May, L.H. (1960) The Utilization of Carbohydrate Reserves in Pasture Plants after Defoliation. Herbage Abstracts, 30, 236-245.

[41] Carvalho, C.A., Da Silva, S.C. and Sbrissia, A.F. (2001) Carboidratos não Estruturais e Acúmulo de Forragem em Pastagens de Cynodonspp. sob Lotação Contínua. Scientia Agricola, 58, 667-674. http://dx.doi.org/10.1590/S0103-90162001000400003

[42] Lupinacci, A.V. (2002) Reservas orgânicas, índice de área foliar e produção de forragem em Brachiaria brizantha, cv. Marandu submetida a intensidade de pastejo por bovinos de corte. Picacicaba, SP, Dissertação (Mestrado)—Escola Superior de Agricultura Luiz de Queiroz, Universidade de São Paulo, São Paulo, 160. 
[43] Rodrigues, R.C., Cabral, L. and Silva, L. (2008) Carboidratos não estruturais e compostos nitrogenados em plantas forrageiras: Importância e métodos analíticos. Ed. UFMT, Cuiabá, 38 p.

[44] Brougham, R.M. (1957) Interception of Light by the Foliage of Pure and Mixed Stands of Pasture Plants. Australian Journal of Agricultural Research, 9, 39-52. http://dx.doi.org/10.1071/AR9580039

[45] Scheffer-Basso, S.M., Scherer, C.V. and Ellwanger, M.F. (2008) Response to Fertilization Perennial Pastures with Pig Slurry: Natural Pasture. Journal of Animal Science, 37, 221-227.

[46] Soares Filho, C.V. (2009) Características morfogenéticas, perdas de nitrogênio por volatilização, reservas orgânicas e sistema radicular do capim Tanzânia fertilizado com doses de nitrogênio. Tese(Livre docência), Universidade Estadual Paulista, Faculdade de Odontologia e curso de Medicina Veterinária, Araçatuba, 154 p.

[47] Moraes, A. (1991) Produtividade animal e dinâmica de uma pastagem de pangola (Digitaria decumbens Stent.), azevém (Lolium multiflorum Lam.)e trevo branco (Trifolium repens L.), submetida a diferentes pressões de pastejo. Tese (Doutorado), Universidade Federal do Rio Grande do Sul, Porto Alegre, 200 p.

[48] Giacomini, A.A., Mattos, W.T. and Mattos, H.B. (20005) Crescimento de raízes dos capins Aruana e Tanzânia submetidos a duas doses de nitrogênio. Revista Brasileira de Zootecnia, 34, 1109-1120. http://dx.doi.org/10.1590/S1516-35982005000400004

[49] Chapman, D. and Lemaire, G. (1996) Tissue Flows in Grazed Plant Communities. In: Hodgson, J. and Illius, A.W., Eds., The Ecology and Management of Grazing Systems, CAB International, Guilford, 3-36.

[50] Lemaire, G., Khaithy, M., Onillon, B., Allirand, J.M., Chartier, M. and Gosse, G. (1992) Dynamics of Accumulation and Partitioning of $\mathrm{N}$ in Leaves, Stems and Roots of Lucerne (Medicago sativa L.) in a Dense Canopy. Annals of Botany, 70, 429-435.

[51] Corsi, M., Martha, J.R. and Pagotto, D.S. (2001) Sistema radicular: Dinâmica e resposta a regimes de desfolha. In: A Produção Animal na Visão dos Brasileiros, FEALQ, Anais... Piracicaba, 838-852.

[52] Marschner, H. (1995) Mineral Nutrition of Higher Plants. 2nd Edition, Academic Press, London, 889 p.

[53] Wardlaw, I.F. (1990) The Control of Carbon Partitioning in Plants. New Phytologist, 116, 341-381. http://dx.doi.org/10.1111/j.1469-8137.1990.tb00524.x 